ISSN 2080-5993

\title{
Krzysztof Biernacki
}

Uniwersytet Ekonomiczny we Wrocławiu

\section{RYZYKO PODATKOWE ROZLICZEŃ WIRTUALNYCH NA PRZYKLADZIE TRANSAKCJI HYIP}

\begin{abstract}
Streszczenie: Dynamiczny rozwój rynków wirtualnych nie pociąga za sobą odpowiednich zmian w przepisach prawa podatkowego. W konsekwencji powstają wątpliwości związane z opodatkowaniem określonych zdarzeń w świecie wirtualnym, w płaszczyźnie m.in. podatków dochodowych. Złożoność polskiego systemu podatkowego oraz połączenie kazuistycznych regulacji z ogólnymi zasadami opodatkowania może w praktyce prowadzić do powstawania barier, które skutecznie zniechęcać mogą do podejmowania przedsięwzięć inwestycyjnych w Internecie. Opracowanie omawia w początkowej części istotę inwestycji opartą na transakcjach typu HYIP, a następnie analizuje potencjalne obszary ryzyka związanego z opodatkowaniem tego typu przedsięwzięć.
\end{abstract}

Słowa kluczowe: inwestycja, podatek, ryzyko podatkowe.

DOI: $10.15611 /$ nof.2014.1.01

\section{Wstęp}

Wzrastająca rola Internetu w życiu codziennym znajduje swoje odzwierciedlenie m.in. w przenoszeniu transakcji zawieranych na rynku finansowym do przestrzeni wirtualnej. Poza możliwością dokonywania rozliczeń, w tym zakupu i sprzedaży w sieci szeroko rozumianych aktywów istniejących realnie, obecnie występują również platformy transakcyjne oparte na samodzielnie stworzonych walutach (np. transakcjach HYIP), na których są one przedmiotem obrotu. Powiązanie ze światem rzeczywistym następuje przez konieczność zakupu tych instrumentów za waluty będące obowiązującym środkiem płatniczym, następnie możliwa jest ich powrotna odsprzedaż. Przykładem takich wirtualnych walut są Liberty Reserve Dollars (LR\$) lub Solid Trust Pay Dollars (STP\$), które swoją nazwę biorą od programów prowadzących transakcje.

O ile tworzenie wartości na potrzeby określonych przestrzeni wirtualnych (np. w grach komputerowych) nie prowadziło do ryzyka podatkowego związanego z koniecznością rozliczenia sprzedaży lub zakupu takich artefaktów, jeżeli nie następowały płatności walutą istniejącą realnie w obiegu gospodarczym, o tyle anali- 
zowane transakcje HYIP prowadzą do rzeczywistego przysporzenia majątkowego w świecie realnym, które co do zasady powinno zostać opodatkowane. Brak szczegółowych regulacji oraz praktyki w tym zakresie niosą ze sobą istotne ryzyko podatkowe dla tych osób, które tego typu inwestycje podejmują.

Niniejsze opracowanie ma na celu weryfikację hipotezy, iż kazuistyczny system podatkowy wiąże się ze zwiększonym ryzykiem podatkowych rozliczeń transakcji w świecie wirtualnym. Celem falsyfikacji zaprezentowanej hipotezy artykuł został podzielony na trzy części.

\section{Transakcje typu HYIP}

HYIP jest skrótem anglojęzycznego określenia inwestycji o wysokiej stopie zwrotu (High Yield Investment Programs) [The HYIP Investors Bible..., s. 3]. Realizowane są one w przestrzeni wirtualnej ze względu na niskie kwoty początkowych inwestycji. Wskazuje się bowiem, że sama istota funkcjonowania takich programów sięga swoją historią początku XX wieku, przy czym w świecie realnym początkowa kwota inwestycji wynosi co na mniej 500 tys. dol. [The HYIP Investors Bible..., s. 4].

Niskie początkowe kwoty inwestycji nie mają wpływu na stopy zwrotów, które kalkulowane są dziennie, tygodniowo lub miesięcznie [http://hyipguide.info/what-is-hyip.html]. Mają one wartości odpowiednio w przedziałach 1-7\%;10-30\% oraz 50-300\%, w zależności od tzw. programu, który prowadzi inwestycje (wskazujące zwrot na podstawie wskaźnika ROI) [http://www.hyipexplorer.com]. Ze względu na ich znaczną liczbę powstały portale monitorujące poszczególne programy, ze wskazaniem stopnia ich wypłacalności, najczęściej w czterostopniowej skali: paying (wypłacalne), waiting (przejściowe - w praktyce takie, które przynajmniej raz nie wypłaciły środków w terminie), problem (niewypłacające środków od kilku dni), not paying (niewypłacalne) ${ }^{1}$.

Inwestycje w programach typu HYIP nie są transparentne, tj. inwestor, wpłacając środki pieniężne, nie wie, w co są one inwestowane. Jedyną informacją jest ogłaszana stopa zwrotu oraz fakty wypłaty depozytu wraz z narosłym zyskiem z inwestycji. Zarówno ograniczony dostęp do informacji, jak i wiele niewypłacalności poszczególnych programów doprowadziły do definiowania inwestycji typu HYIP jako piramid finansowych opartych na schemacie Ponziego². Amerykańska Komisja Papierów Wartościowych i Giełd (US Securities and Exchange Commission, SEC) określiła programy typu HYIP mianem fraud (nadużycie, oszustwo) i przestrzega przed podejmowaniem takich inwestycji [http:/www.sec.gov/investor/alerts/ socialmediaandfraud.pdf]. W Stanach Zjednoczonych SEC stara się monitorować prowadzenie takich programów i od kilku lat wnoszone są pozwy przeciwko orga-

${ }^{1}$ Na przykład portale: [http://uhyips.com; http://hyip24.net; http://hyipbanker.com].

${ }^{2}$ Definicję taką można znaleźć w Wikipedii zarówno polskiej [http://pl.wikipedia.org/wiki/HYIP], jak i w angielskojęzycznej [http://en.wikipedia.org/wiki/High-yield_investment_program]. 
nizatorom. Głównym zarzutem jest brak rejestracji prowadzonej działalności o charakterze inwestycyjno-finansowym oraz tworzenie piramid finansowych. W Polsce Komisja Nadzoru Finansowego nie podjęła dotychczas żadnych działań mających na celu monitoring rynku tego typu inwestycji, jak również nie zajęła stanowiska co do jego legalności w świetle rajowych przepisów prawa. Jest to o tyle istotne, że polscy obywatele uczestniczą $\mathrm{w}$ takich programach inwestycyjnych za pośrednictwem stron internetowych, nie mając przy tym obiektywnej informacji ze strony organów nadzoru państwowego.

Do określenia ryzyka podatkowego rozliczeń tego typu inwestycji istotne jest opisanie jej procedury. Z punktu widzenia inwestora polskiego pierwszym krokiem jest rejestracja na stronie jednego z programów (np. http://tureprofit.com/?ref=uHYIPs.com). Następnie wpłaca się kwotę inwestycji za pośrednictwem dostępnych tzw. procesorów płatniczych. Na przykład wskazany powyżej program akceptuje Liberty Reserve, Perfect Money, SolidTrustPay oraz EgoPay. Procesory te tworzą konta (depozyty) na wpłacane kwoty w dolarach amerykańskich i umożliwiają przelewy na inne konta tylko w obrębie Liberty Reserve. Zatem odbiorca płatności również musi mieć konto $\mathrm{w}$ tym procesorze ( $\mathrm{w}$ tym wypadku program prowadzący HYIP), a wszelkie rozliczenia również następują w dolarach. Już zatem na początku powstaje konieczność zamiany waluty krajowej na dolary amerykańskie, za pośrednictwem np. kantorów internetowych; następnie od każdej transakcji w ramach procesora płatniczego potrącana jest prowizja.

$\mathrm{W}$ trakcie trwania programu konto uczestnika powiększa się o zgromadzone zyski. Nie jest zdefiniowane, czy mają one charakter pasywny (np. odsetki) czy też aktywny (np. dywidendy, dodatnia różnica ze zbycia aktywów). Jest to tylko ujęcie memoriałowe. Faktyczna realizacja inwestycji następuje w momencie wycofania środków z programu przez inwestora. Następuje wówczas zwrot środków na konto procesora płatniczego, jego wypłata i przewalutowanie dla uczestnika programu.

$\mathrm{W}$ tak ujętej procedurze inwestycji potencjalne ryzyko podatkowe może pojawić się co najmniej w trzech obszarach: kwalifikacji podmiotowej inwestora, określeniu przedmiotu transakcji na potrzeby podatków zarówno dochodowych, jak i obrotowych oraz nieujawnieniu uzyskanego dochodu (kwalifikacja formalna). Każdy z tych obszarów zostanie omówiony oddzielnie.

\section{Inwestor jako podatnik}

Przepisy podatkowe różnicują metodę kalkulacji podatku dochodowego oraz opodatkowanie podatkami obrotowymi w zależności od statusu podatnika. Dla uproszczenia przyjęto założenie, że potencjalnym inwestorem jest osoba fizyczna, która w obszarze podatków dochodowych może być traktowana jako konsument lub jako podmiot prowadzący działalność gospodarczą.

W pierwszym przypadku brak wyboru szczególnej formy opodatkowania prowadził będzie do kwalifikacji uzyskiwanych dochodów z inwestycji w ramach źródła 
„kapitały pieniężne i prawa majątkowe” (art. 10 ust. 1 pkt 7 Pdof ${ }^{3}$ ). Ich rozliczenie będzie miało charakter roczny, a ewidencja oparta jest co do zasady na metodzie kasowej. Przy czym istnienie jednego źródła dochodów dla tego typu inwestycji prowadzi jednak do zróżnicowania metod opodatkowania dochodów pasywnych i aktywnych, o czym będzie mowa w części poświęconej kwalifikacji przedmiotowej transakcji.

Alternatywnym rozwiązaniem jest opodatkowanie uzyskiwanych dochodów w ramach prowadzonej działalności gospodarczej. Przepisy zarówno o podatkach dochodowych (art. 5a pkt 6 Pdof), jak i o podatku od towarów i usług (dalej jako podatek VAT, art. 15 ust. 2 UoVat $^{4}$ ) wprowadzają samoistne definicje działalności gospodarczej. Mają one charakter obiektywny, niezależny od odjętych czynności rejestracyjno-ewidencyjnych, i determinują uzyskanie statusu przedsiębiorcy na przesłankach faktycznego wykonywania określonego rodzaju czynności [Bartosiewicz, Kubacki 2012, s. 134]. Ze względu na nieostrość pojęć użytych przez ustawodawcę w przytoczonych przepisach prowadzenie inwestycji finansowych, takich jak programy HYIP, może być traktowane jako działalność gospodarcza. W takim przypadku dochody powinny być rozliczone w ramach źródła ,pozarolnicza działalność gospodarcza" (art. 10 ust. 1 pkt 3 Pdof), natomiast inwestor staje się z mocy pracy podatnikiem podatku od towarów i usług (VAT). Do kwoty rocznego obrotu w wysokości 150 tys. zł jest on zwolniony podmiotowo od tego podatku (art. 113 UoVat), powyżej tej wartości powstaje jednak ryzyko kwalifikacji prowadzonych transakcji jako czynności zwolnionych. Treść art. 43 ust. 1 pkt 37-41 UoVat nie determinuje zwolnienia obligatoryjnego przy samodzielnym prowadzeniu inwestycji, gdyż okoliczność taka nie jest wymieniona w katalogu czynności zwolnionych.

Metoda źródeł określona w przepisach o podatku dochodowym od osób fizycznych nie ma zastosowania w podatku dochodowym od osób prawnych. Następuje w nim bowiem łączenie przychodów ze wszystkich źródeł, a następnie jest pomniejszany o sumę poniesionych kosztów (art. 7 ust. 1 Pdop $^{5}$ ). Mimo że taka metoda kalkulacji wyłącza ryzyko związane z kwalifikacją dochodu do określonego źródła, w praktyce nikt nie zakłada spółek kapitałowych w celu prowadzenia inwestycji w ramach programów HYIP.

Mając na uwadze, iż najczęściej inwestorzy dokonują transakcji nie w ramach prowadzonej działalności gospodarczej, w podatku VAT mogą oni nie być kwalifikowani jako podatnicy tego podatku. W konsekwencji jeżeli przyjmujemy, iż realizacja inwestycji w ramach programów HYIP jest zakupem instrumentów finansowych będących prawami majątkowymi, podatnicy podlegać będą podatkowi od czynności cywilnoprawnych (por. art. 1 ust. 1 pkt 1 lit. a UoPCC ${ }^{6}$ ). Zdarzenie takie,

${ }^{3}$ [Ustawa z dnia 26 lipca 1991 r.], dalej jako Pdof.

${ }^{4}$ [Ustawa z dnia 11 marca 2004 r. ...], dalej jako UoVat.

${ }_{5}^{5}$ [Ustawa z dnia 15 lutego 1992 r. ...], dalej jako Pdop.

${ }^{6}$ [Ustawa z dnia 9 września 2000 r.], dalej jako UoPCC). 
jeżeli nie jest realizowane za pośrednictwem instytucji finansowych, nie korzysta ze zwolnień w tym podatku (art. 9 pkt 9 UoPCC). Stawka podatku wynosić będzie w tym przypadku 1\% wartości każdorazowo dokonanej transakcji (art. 7 ust. 1 pkt 1 lit. b UoPCC). Fakt zawierania transakcji na zagranicznych serwerach nie będzie wyłączał obowiązku opodatkowania sprzedaży po stronie polskiego inwestora (art. 1 ust. 4 UoPCC).

Podsumowując wątek związany z ryzykiem kwalifikacji podmiotowej inwestora jako podatnika, należy wskazać na trudność w określeniu, czy prowadzenie inwestycji w ramach programów HYIP należałoby rozliczać jako działalność gospodarczą czy też jako dochody konsumenta zaliczane do źródła „kapitały pieniężne”. Ostateczna decyzja przesądzać będzie nie tylko o rozliczeniu podatku dochodowego, ale także o podatku VAT. W szczególności ryzyko to będzie wzrastać w sytuacji, gdy inwestor będzie uzyskiwał równolegle inne dochody, zwłaszcza z prowadzonej działalności gospodarczej. W nawiązaniu do podobnej sytuacji z rozliczaniem tzw. opcji walutowych pojawia się ryzyko odrębnego opodatkowania zysków z programów inwestycyjnych typu HYIP, jak również konieczność wyłączenia straty z prowadzonej działalności gospodarczej. Może mieć to w konsekwencji istotne znaczenie dla ostatecznego obciążenia podatkowego określonej osoby.

\section{Kwalifikacja przedmiotowa}

Przy analizie opodatkowania przedmiotu transakcji w ramach programów HYIP niezbędne jest odniesienie się do poszczególnych zdarzeń, mogących kreować obowiązek i zobowiązanie podatkowe dla inwestora. Pierwszym z nich jest wpłata kwoty inwestycji i jej zamiana na walutę wykorzystywaną w ramach procesora płatniczego. W płaszczyźnie podatkowej dochodzi zatem do wydatku, który kosztem stanie się w momencie realizacji inwestycji (art. 23 ust. 1 pkt 38 oraz 38a Pdof). Konieczność przewalutowania (np. w kantorze internetowym) może tworzyć koszt wynikający z prowizji od takiej transakcji, co będzie miało miejsce także w ramach samego procesu inwestycyjnego, jeżeli prowizja będzie pobierana od poszczególnych zdarzeń obejmujących zakup i sprzedaż instrumentów w ramach określonego programu. Prowizja ta powiększać będzie koszty danej inwestycji i powinna być rozliczana w momencie jej zakończenia.

W okresie trwania inwestycji pojawia się ryzyko prawidłowego określenia momentu powstania obowiązku podatkowego od otrzymanych zysków. Mimo iż przepisy krajowe nie dokonują dystynkcji pomiędzy opodatkowaniem pasywnych i aktywnych instrumentów finansowych [Jamroży, Kudert 2007, s. 23], przyjąc należy, iż w inwestycjach pierwszej grupy podatek pojawi się w momencie wypłaty zysku lub postawienia go do dyspozycji ${ }^{7}$, natomiast $\mathrm{w}$ inwestycjach o charakterze

${ }^{7}$ Wniosek ten został wyprowadzony na podstawie analogii do opodatkowania pasywnego świadczenia w postaci odsetek (por. art. 11 ust. 1 w zw. z art. 17 ust. 1 pkt 1 Pdof). 
aktywnym obowiązek podatkowy powstanie dopiero w momencie sprzedaży instrumentów finansowych. Dodatkowo kwotowanie w walucie obcej wartości inwestycji prowadzić będzie do powstania różnic kursowych, które tworzą ryzyko ich ujęcia jako przychodów lub kosztów podatkowych. W tym aspekcie warto też podkreślić, iż prawidłowa kwalifikacja przedmiotu transakcji będzie niosła ze sobą możliwość rozliczenia straty z jednej inwestycji z zyskiem z drugiej. Polskie przepisy podatkowe wyłączają bowiem w niektórych wypadkach możliwość rozliczenia straty z dochodem w ramach źródła „kapitały pieniężne i prawa majątkowe” (por. art. 30b ust.1 Pdof). Powstaje zatem ryzyko prawidłowego określenia dochodu do opodatkowania, który w niektórych przypadkach nie może być zmniejszany o poniesione przez podatnika straty.

Rozwiązaniem optymalnym z punktu widzenia podatnika byłoby potraktowanie całości inwestycji jako jednej transakcji, w której wynik byłby rozliczany kasowo, tj. wpłacona kwota na moment zakończenia inwestycji byłaby porównywana z osiągniętym przychodem, a różnica podlegałaby opodatkowaniu. Mimo to, kiedy przyjmie się kasową metodę opodatkowania, powstaje ryzyko określenia prawidłowej podstawy opodatkowania, która uzależniona będzie od rodzaju osiąganych przychodów (przychód pasywny versus przychód aktywny). Jeżeli charakter tych zysków zbliżony byłby do odsetek, wówczas stawka $19 \%$ ma zastosowanie do osiągniętego przez podatnika przychodu (art. 30a ust. 1 pkt 1 Pdof). W przypadku innych instrumentów stawka ta będzie obejmowała dochód będący nadwyżką przychodu nad kosztami jego uzyskania.

Konkludując, należy stwierdzić, że obszary ryzyka podatkowego w podatku dochodowym obejmują zarówno moment kwalifikacji przychodu lub kosztu, jak i zasady ustalania podstawy opodatkowania. Ryzyko to nie obejmuje stawki podatku, która uzależniona jest od podmiotowego statusu inwestora jako podatnika.

W podatku VAT inwestycja może być kwalifikowana jako świadczenie usług (art. 8 ust. 1 UoVat). Jak wskazano przy kwalifikacji podmiotowej, wątpliwości pojawiają się przy określeniu zasad opodatkowania takich transakcji. Wskazane bowiem przepisy art. 43 UoVat nie dają podstawy do stosowania zwolnienia w tym podatku. Jedyną możliwością jest wykorzystanie zwolnienia podmiotowego.

\section{Ryzyko formalne}

Istnienie ryzyka formalnego związane jest $\mathrm{z}$ brakiem prawidłowo prowadzonej ewidencji na potrzeby ustalenia wymiaru podatku. Najszerszy zakres ryzyka dotyczy tzw. dochodów z nieujawnionych źródeł, które mogą być objęte stawką 75-procentowego podatku od posiadanego majątku, który nie znajduje swojego pokrycia w źródłach znanych organom podatkowym (art. 30 ust. 1 pkt 7 Pdof). Sytuacja taka może mieć miejsce, gdy działalność inwestycyjna byłaby nieopodatkowana ze względu na brak jej ujawnienia dla organów podatkowych. 
Niemożność wymiaru podatku ze względu na brak posiadanej dokumentacji uzasadnia dokonanie oszacowania podstawy opodatkowania i określenie na tej podstawie kwoty zobowiązania podatkowego (art. 23 Ordynacji ${ }^{8}$ ). Ze względu na specyfikę inwestycji w ramach programów HYIP podatnik może nie posiadać materialnej dokumentacji zawieranych transakcji. Najczęściej jedynym ich dowodem będzie przepływ środków pieniężnych na jego koncie bankowym w walucie krajowej. W przypadku zawierania transakcji za pośrednictwem kilku kont lub kont zagranicznych, co może być uzasadnione mniejszymi kosztami przewalutowań, brak stosownych dokumentów prowadzić może do szacunkowego wymiaru podatku.

\section{Podsumowanie}

Podsumowując, należy stwierdzić, iż podjęcie inwestycji w ramach programów HYIP wiązać się może z trzema wymienionymi obszarami ryzyka podatkowego, przy czym największe istnieje w podatku dochodowym od osób fizycznych. Warto wskazać, iż ryzyko to wynika z trudności w zakwalifikowaniu otrzymywanego przez inwestora dochodu, a nie ze specyfiki inwestycji typu HYIP. Tym samym może się ono pojawić w opisanym zakresie przy większości inwestycji dokonywanych w przestrzeni wirtualnej.

De lege ferenda postulować należy zwiększenie ogólności i ujednolicenie zasad opodatkowania otrzymywanych świadczeń w ramach inwestycji o charakterze finansowym zarówno w świecie realnym, jak i w Internecie. Nieuzasadnione bowiem wydaje się zwiększenie kazuistyczności przepisów i dążenie do wymienienia wszystkich potencjalnych dochodów w przepisach podatkowych. Dynamika zmian i tworzenie się coraz to nowych projektów wirtualnych inwestycji ${ }^{9}$ uniemożliwiałyby w praktyce ich bieżące uwzględnianie w przepisach podatkowych.

\section{Literatura}

Bartosiewicz A., Kubacki R., Komentarz do Ustawy o podatku dochodowym od osób fizycznych, Wydawnictwo Wolters Kluwer, Warszawa 2012.

Jamroży M., Kudert St., Optymalizacja opodatkowania dochodów przedsiębiorców, Wydawnictwo Wolters Kluwer, Warszawa 2007.

Kowanda C., Bitcoin - waluta internetowa na kryzys, „Polityka” z dnia 09.04.2013.

The HYIP Investors Bible, e-book dostępny na stronie: http://www.hyip.com/ht/pdf/hyip.guide.pl.pdf.

\section{Netografia}

http://hyipguide.info/what-is-hyip.html.

http://www.hyipexplorer.com.

${ }^{8}$ Ustawa z dnia 29 sierpnia 1997 r., dalej jako Ordynacja.

9 Jako przykład wskazać można ,internetową” walutę BitCoin, w wypadku której ostatnie kilkanaście miesięcy umożliwiło jej zastosowania przy transakcjach realnymi dobrami [Kowanda 2013, s. 34]. 
http://uhyips.com.

http://hyip24.net.

http://hyipbanker.com.

http://pl.wikipedia.org/wiki/HYIP.

http://en.wikipedia.org/wiki/High-yield_investment_program.

http://www.sec.gov/investor/alerts/socialmediaandfraud.pdf.

\section{Akty prawne}

Ustawa z dnia 26 lipca 1991 r. o podatku dochodowym od osób fizycznych (DzU nr 80, poz. 350 ze zm.). Ustawa z dnia 15 lutego 1992 r. o podatku dochodowym od osób prawnych (DzU nr 21, poz. 86 ze zm.). Ustawa z dnia 29 sierpnia 1997 r. Ordynacja podatkowa (DzU nr 137, poz. 926 ze zm.).

Ustawa z dnia 9 września 2000 r. o podatku od czynności cywilnoprawnych (DzU nr 86, poz. 959 ze zm.). Ustawa z dnia 11 marca 2004 r. o podatku od towarów i usług (DzU nr 54, poz. 535 ze zm.).

\section{TAX RISK OF INTERNET SETTLEMENTS EXEMPLIFIED BY HYIP TRANSACTION}

Summary: Nowadays Internet allows to make settlements in virtual currency, which can be exemplified by HYIP transaction. This abbreviation means High Yield Investment Programs and provides the possibility to invest for short periods with high rate of return. However, achieving income results in the necessity to tax such a gain. Because of the methodology of calculation of Polish taxes, especially income taxes, virtual settlements generate tax risk in three areas: subject, object and formal requirements of the taxation. In conclusion this tax risk may negatively influence the development of such investments in virtual space.

Keywords: investment, tax, tax risk. 